\title{
Specific induction of a cuticle-degrading protease of the insect pathogenic fungus Metarhizium anisopliae
}

\author{
Ian C. Paterson, A. Keith Charnley, Richard M. Cooper \\ and John M. Clarkson
}

Author for correspondence: John M. Clarkson. Tel: +44 225 826826. Fax: +44 225826779.

Microbial Pathogenicity Group, School of Biological Sciences, University of Bath, Claverton Down, Bath BA2 7AY, UK

\begin{abstract}
The insect pathogenic fungus Metarhizium anisopliae produces several extracellular cuticle-degrading proteases and evidence is consistent that one of these, a chymoelastase PR1, is a determinant of pathogenicity. We have shown previously that the wide-domain regulatory circuits of carbon and nitrogen derepression regulate PR1 production. In the present work we have established in addition that PR1 is specifically induced by insect cuticle, but not by other soluble or insoluble proteinaceous substrates. The feeding of elastin or collagen to derepressed established mycelium (starved for carbon and nitrogen) did not enhance PR1 production significantly and the soluble proteins BSA and gelatin rapidly and completely repressed PR1. The carbohydrate polymers cellulose and xylan gave derepressed basal levels of PR1. However, addition of locust cuticle enhanced PR1 production to a level approximately 10-fold that of derepressed mycelium. In order to establish if the enhancing effect of insect cuticle on PR1 production was due to specific induction or merely a reflection of enhanced growth on this insoluble dual carbon and nitrogen source, ergosterol was used as a measure of fungal growth. Expressing enzyme activity per mg dry weight showed that PR1 production in cuticle cultures increased approximately five- and ninefold after 12 and $24 \mathrm{~h}$ growth compared with elastin-grown cultures. Thus, the substantial increase in PR1 production on cuticle was shown not to be a function of fungal growth and this confirms that PR1 is induced by a component of insect cuticle; we believe this is the first report of induction by a specific substrate for any microbial protease.
\end{abstract}

Keywords: Metarbizium anisopliae, insect pathogen, protease regulation

\section{INTRODUCTION}

Insect pathogenic fungi, and in particular the Deuteromycete Metarhizium anisopliae, have great potential for use in pest control. Infection occurs directly through the insect exoskeleton or cuticle and penetration is effected by a combination of mechanical pressure and enzymic degradation (Charnley, 1984). Biochemical studies (reviewed by Charnley \& St Leger, 1991) have provided strong evidence that an extracellular chymoelastase, PR1, is essential for cuticle penetration and is a determinant of pathogenicity (St Leger et al., 1988a). Briefly, protease is first in a sequence of cuticle-degrading enzymes produced in vitro on host cuticle and PR1 is adapted to degrade extensively cuticular protein (St Leger et al., 1987a). PR1 is the only cuticle-degrading enzyme produced in high amounts by all pathogenic isolates of Metarbizium ( $\mathrm{St}$ Leger et al., 1987b). It is produced in high levels by the fungus during host penetration (St Leger et al., 1987c) and specific inhibition of PR1 delays disease symptoms and mortality of the tobacco hornworm Manduca sexta (St Leger et al., 1988a).

Understanding the role of PR1 in cuticle penetration is facilitated by studying its regulation. It has previously been reported that PR 1 is produced under conditions of carbon and nitrogen starvation (St Leger et al., 1988b, 1991). Proteases are similarly derepressed in many $A s$ pergillus species (Cohen, 1981) and Schizophyllum commune (Sessoms \& Lilly, 1986). However, we report here an additional level of regulation of PR1 by $M$. anisopliae, that of specific induction by insect cuticle but not by other insoluble or soluble proteinaceous substrates. 


\section{METHODS}

Growth and culture conditions. $M$. anisopliae isolate ME1 (origin: pecan weevil) originally obtained from Tate and Lyle, Group Research and Development Laboratory, Reading, UK, was used throughout this work and was cultured routinely on 1/4-strength Sabouraud's dextrose agar (SDA) containing $0 \cdot 25 \%(\mathrm{w} / \mathrm{v})$ yeast extract at $27{ }^{\circ} \mathrm{C}$. Conidial suspensions were prepared from actively growing cultures by washing with $0.05 \%$ Tween 80 . The resulting suspensions were centrifuged at $3000 \mathrm{~g}$ for $5 \mathrm{~min}$ and then resuspended in sterile distilled water. Liquid cultures were grown either in modified basal salts plus trace elements (Cooper \& Wood, 1975), which contained per litre, $1 \mathrm{~g} \mathrm{KH}_{2} \mathrm{PO}_{4}, 0.5 \mathrm{~g} \mathrm{MgSO}_{4} .7 \mathrm{H}_{2} \mathrm{O}$ and $10 \mathrm{ml}$ trace element solution which comprised $0.2 \%(\mathrm{w} / \mathrm{v}) \mathrm{FeSO}_{4} \cdot 7 \mathrm{H}_{2} \mathrm{O}$, $1 \%(\mathrm{w} / \mathrm{v}) \mathrm{ZnSO}_{4}, 0.02 \%$ (w/v) $\mathrm{NaMoO}_{4} \cdot 2 \mathrm{H}_{2} \mathrm{O}, 0.02 \%(\mathrm{w} / \mathrm{v})$ $\mathrm{CuSO}_{4} .5 \mathrm{H}_{2} \mathrm{O}$ and $0.02 \%$ (w/v) $\mathrm{MnCl}_{2} .4 \mathrm{H}_{2} \mathrm{O}$, plus $50 \mathrm{mM}$ MES (a non-metabolizable buffer) $\mathrm{pH} \mathrm{6,} \mathrm{or} \mathrm{in} \mathrm{complete}$ medium (CM), which consisted of Modified Czapek Dox (Oxoid) supplemented with $2 \mathrm{~g} \mathrm{l}^{-1}$ of each of casein hydrolysate, mycological peptone, yeast extract and malt extract. Carbon/ nitrogen sources were supplied at $1 \%(\mathrm{w} / \mathrm{v})$ because BSA concentrations above $1 \%$ repress protease production (I. C. Paterson, unpublished). All polymeric carbon/nitrogen sources with the exception of insect cuticle were from Sigma. Comminuted cuticle from adult desert locusts (Schistocerca gregaria) was prepared essentially as described by Andersen (1980). Approximately 100 locusts were frozen at $-20^{\circ} \mathrm{C}$ for $1 \mathrm{~h}$ and then homogenized in a Waring blender in $1 \%(\mathrm{w} / \mathrm{v})$ potassium tetraborate. The cuticle pieces were washed extensively in distilled water, stirred overnight in $1 \%(\mathrm{w} / \mathrm{v})$ potassium tetraborate and then dried at $37^{\circ} \mathrm{C}$. The cuticle pieces were then milled to a fine powder in a Glen-Creston hammer mill (DEH48) using a $0.5 \mathrm{~mm}$ sieve. The powder was washed in $1 \%$ potassium tetraborate and finally in distilled water, allowed to settle and any floating material removed. This method retains cuticular protein.

Transfer experiments. $\mathrm{CM}, 100 \mathrm{ml}$ in $250 \mathrm{ml}$ Erlenmeyer flasks, was inoculated with $4 \times 10^{6}$ conidia and incubated at $27^{\circ} \mathrm{C}$ in an orbital shaker (150 r.p.m.) for $3 \mathrm{~d}$ in order to establish extensive fungal growth. Cultures developed as uniform submerged mycelial balls with no sporulation evident; the morphology of fungal cultures remained constant over the duration of the experiments. The culture was sieved through two layers of sterile muslin. Retained mycelium was washed with sterile basal salts medium, transferred to $100 \mathrm{ml}$ basal salts medium and then incubated for a further $24 \mathrm{~h}$ under the same conditions as above to ensure complete catabolite derepression. Potential inducers of protease were then added at $1 \%(\mathrm{w} / \mathrm{v})$ and PR 1 activity in the culture supernatant was assayed for up to $24 \mathrm{~h}$.

Enzyme assays. PR1 was assayed by monitoring at $410 \mathrm{~nm}$ the release of nitroanilide (NA) from the peptide substrate succinylAla-Ala-Pro-Phe-NA essentially as described by St Leger $e t$ al. (1987a) except that $100 \mathrm{mM}$ Tris/HCl buffer $\mathrm{pH} 8$ was used. Activity is expressed as nmol NA released $\mathrm{ml}^{-1} \mathrm{~min}^{-1}$.

Chemicals. All chemicals, unless otherwise stated, were from Sigma. HPLC grade solvents were from Rathburns.

High performance liquid chromatography (HPLC). HPLC was performed on a Gilson system comprising two 303 pumps, a 811B dynamic mixer, a 401 dilutor, a 231 sample injector, a Rheodyne injection valve fitted with a $20 \mu \mathrm{l}$ loop and a Gilson 118 UV dual wavelength detector. The system was controlled by the Gilson 714 manager on an Opus PC.

Fungal growth assessment. In order to measure dry weight, mycelium from liquid cultures was collected over a Buchner funnel and the mycelial mat dried to a constant weight at $70^{\circ} \mathrm{C}$. The dried mycelium was cooled to room temperature in a desiccator before weighing.

The procedure used for the extraction and quantification of ergosterol was a modification of the method described by Seitz et al. (1979). Mycelium from $100 \mathrm{ml}$ liquid culture was collected over a Buchner funnel and homogenized for $1 \mathrm{~min}$ on a 'Pulse Matic 16' osterizer in $40 \mathrm{ml}$ methanol/dichloromethane $(2: 1$, $\mathrm{v} / \mathrm{v}$ ). After $30 \mathrm{~min}$ the suspension was filtered over a Buchner funnel and the residue washed with $40 \mathrm{ml}$ dichloromethane and then $40 \mathrm{ml} 2 \mathrm{M} \mathrm{KCl}$ in $0.5 \mathrm{M}$ potassium phosphate buffer $(\mathrm{pH} \mathrm{7.4)}$. The filtrate and the washings were combined and the aqueous phase discarded. The organic phase was evaporated to dryness under reduced pressure at $40^{\circ} \mathrm{C}$ in a rotary evaporator. The solid was saponified in $30 \mathrm{ml} 1 \mathrm{M} \mathrm{KOH}$ in $95 \%(\mathrm{v} / \mathrm{v})$ ethanol for $1 \mathrm{~h}$ at $70^{\circ} \mathrm{C}$. Once cool, $60 \mathrm{ml}$ distilled $\mathrm{H}_{2} \mathrm{O}$ was added and the non-saponified fraction extracted with three $100 \mathrm{ml}$ washings of light petroleum. The three washings were combined and evaporated to dryness under reduced pressure at room temperature in a totary evaporator. The solid obtained was stored under nitrogen in sealed tubes at $4{ }^{\circ} \mathrm{C}$ until required. Ergosterol was separated and quantified by reverse-phase HPLC using a Rainin C18 column with detection at $282 \mathrm{~nm}$. A mobile phase of $95 \%(\mathrm{v} / \mathrm{v})$ methanol and flow rate of $2 \mathrm{ml} \mathrm{min}^{-1}$ gave good separation of the ergosterol peak from other extracted sterols; ergosterol standard (Fluka) gave a retention time of $10.5 \mathrm{~min}$. Ergosterol converts to ergocalciferol (vitamin D) upon exposure to UV light (Tuksida, 1980); therefore all samples were stored in the dark. Ergocalciferol standard (Fluka) had a retention time of $7.5 \mathrm{~min}$ and could easily be distinguished from the ergosterol peak. A calibration curve was produced using ergosterol standard.

Fast atom bombardment mass spectrometry. A VG Analytical $7070 \mathrm{E}$ mass spectrometer was utilized with a mass spectrometry services data system to obtain mass spectra of standard and extracted ergosterol. Xenon gas was used in the atom gun running at $8 \mathrm{kV}$ with 3-nitrobenzyl alcohol as the matrix.

\section{RESULTS}

\section{Effect of different carbon and nitrogen sources on protease production}

Mycelium from $3 \mathrm{~d}$ CM cultures was incubated for $24 \mathrm{~h}$ in basal salts medium lacking both $\mathrm{C}$ and $\mathrm{N}$; after this period of starvation different $\mathrm{C}$ and $\mathrm{N}$ sources $(1 \%, \mathrm{w} / \mathrm{v})$ were added and PR 1 activity was assayed for up to $24 \mathrm{~h}$ (Table 1). Addition of elastin, collagen, cellulose or xylan did not enhance PR1 production above basal levels $(-\mathrm{C}-\mathrm{N})$ by $16 \mathrm{~h}$ or $24 \mathrm{~h}$ and the soluble proteins BSA and gelatin rapidly and completely repressed PR1 production. However, addition of locust cuticle enhanced PR 1 production to a level approximately 10 times that of control $(-\mathrm{C}-\mathrm{N})$ flasks after $16 \mathrm{~h}$ and approximately 6 times after $24 \mathrm{~h}$; no effect was apparent after $8 \mathrm{~h}$. Some enhancement was evident with elastin and collagen $8 \mathrm{~h}$ after adding the protein, but PR1 levels subsequently fell to that of the control flasks. Experiments designed to measure the binding of PR1 to insoluble substrates demonstrated that the enhanced PR1 levels in cuticlecontaining cultures reflected enzyme production and were not an artifact of the differential binding of enzyme to substrate (data not shown). 
Table 1. PR1 production by derepressed mycelium of $M$. anisopliae on a range of polymeric substrates

\begin{tabular}{|lccc|}
\hline $\begin{array}{l}\text { C/N source } \\
\mathbf{( 1 \%}, \mathbf{w} / \mathbf{v})\end{array}$ & \multicolumn{3}{c|}{ Enzyme activity* } \\
\cline { 2 - 4 } & $\mathbf{8} \mathbf{h}$ & $\mathbf{1 6} \mathbf{~ h}$ & $\mathbf{2 4} \mathbf{~ h}$ \\
\hline Control (-C-N) & $211 \pm 15$ & $293 \pm 15$ & $580 \pm 33$ \\
Cuticle & $140 \pm 50$ & $2842 \pm 76$ & $3355 \pm 107$ \\
Elastin & $560 \pm 28$ & $298 \pm 11$ & $245 \pm 13$ \\
Collagen & $725 \pm 40$ & $396 \pm 21$ & $311 \pm 27$ \\
BSA & 0 & 0 & 0 \\
Gelatin & 0 & 0 & 0 \\
Cellulose & $97 \pm 18$ & $89 \pm 28$ & $112 \pm 32$ \\
Xylan & $191 \pm 17$ & $271 \pm 12$ & $291 \pm 22$ \\
\hline
\end{tabular}

* Mean activity \pm SD from three replicates 8,16 and $24 \mathrm{~h}$ after addition of $\mathrm{C} / \mathrm{N}$ source to mycelium starved of $\mathrm{C}$ and $\mathrm{N}$ for $24 \mathrm{~h}$. Enzyme activities are expressed as nmol nitroanilide released $\mathrm{ml}^{-1} \mathrm{~min}^{-1}$ from Suc-Ala-Ala-Pro-Phe-NA and are representative of three similar experiments

Table 2. Effect of carbon, nitrogen or sulphur deficiency on PR1 production by $M$. anisopliae

\begin{tabular}{|c|c|c|}
\hline \multirow{2}{*}{$\begin{array}{l}\mathrm{C} / \mathrm{N} \text { source } \\
(1 \%, w / v)\end{array}$} & \multicolumn{2}{|c|}{ Enzyme activity* } \\
\hline & $8 \mathrm{~h}$ & $16 \mathrm{~h}$ \\
\hline$-\mathrm{C}-\mathrm{N}+$ cuticle & $159 \pm 31$ & $818 \pm 66$ \\
\hline$-\mathrm{C}+$ cuticle & 0 & 0 \\
\hline$-\mathrm{N}+$ cuticle & $57 \pm 16$ & $255 \pm 27$ \\
\hline$-S+$ cuticle & $\overline{0}$ & $\overline{0}$ \\
\hline$-\mathrm{C}-\mathrm{N}+\mathrm{BSA}$ & 0 & 0 \\
\hline$-\mathrm{C}+\mathrm{BSA}$ & 0 & 0 \\
\hline$-N+B S A$ & 0 & 0 \\
\hline$-S+B S A$ & 0 & 0 \\
\hline$-\mathrm{C}-\mathrm{N}$ & $9 \pm 4$ & $41 \pm 6$ \\
\hline$-\mathrm{C}$ & 0 & 0 \\
\hline$-\mathrm{N}$ & 0 & 0 \\
\hline$-\mathrm{S}$ & 0 & 0 \\
\hline
\end{tabular}

* Mean activity \pm SD from three replicates 8 and $16 \mathrm{~h}$ after the transfer of mycelia to basal salts deficient in one of $\mathrm{C}, \mathrm{N}$ or $\mathrm{S}$, in the presence or absence of cuticle or BSA $(1 \%, w / v)$. Enzyme activities are expressed as nmol nitroanilide released $\mathrm{ml}^{-1} \mathrm{~min}^{-1}$ from Suc-Ala-Ala-Pro-Phe-NA and are representative of three similar experiments.

\section{Effect of nutrient limitation on protease production}

Mycelium from $3 \mathrm{~d}$ CM cultures was transferred to basal salts deficient in one of $\mathrm{C}, \mathrm{N}$ or $\mathrm{S}$ plus or minus either BSA or cuticle. The medium used was buffered basal salts plus trace elements plus sucrose $(1 \%, \mathrm{w} / \mathrm{v})$ or $\mathrm{NH}_{4} \mathrm{Cl}(0 \cdot 2 \%$, $\mathrm{w} / \mathrm{v})$. Medium deficient in $\mathrm{S}$ contained $\mathrm{MgCl}_{2}$ instead of $\mathrm{MgSO}_{4} \cdot 7 \mathrm{H}_{2} \mathrm{O}$; similarly chlorides were substituted for the sulphates in the trace elements. Protease activity was measured 8 and $16 \mathrm{~h}$ after transfer.
PR1 was repressed completely in all media containing $\mathrm{N}$ and greatly reduced in media containing $\mathrm{C}$ (Table 2 ). No PR1 was produced in media lacking $\mathrm{N}$ (but containing C) unless cuticle was present, in which case PR1 levels were approximately $30 \%$ of those produced in $-\mathrm{C}-\mathrm{N}$ media plus cuticle. No PR1 was produced in media lacking only $\mathrm{S}$. Again, basal levels were detected in the absence of both $\mathrm{C}$ and $\mathrm{N}$.

\section{Ergosterol as a measure of mycelial biomass in $\boldsymbol{M}$. anisopliae}

It was necessary to establish if the enhancing effect of cuticle on PR1 production was a result of specific induction or merely a reflection of enhanced growth of $M$. anisopliae on this dual carbon and nitrogen source. However, separation of mycelium from insoluble substrates is impracticable, which precludes comparisons of mycelial dry weight. The assay methods commonly used for measuring fungal biomass on solid substrates are chitin and ergosterol estimation (Matcham et al., 1984). Chitin is also an integral part of insect cuticle structure and thus ergosterol content was considered as a means of estimating biomass in this study. It was first essential to establish the validity of this assay for growth of $M$. anisopliae.

Ergosterol was extracted from mycelium and analysed by HPLC. The chromatogram showed a peak with the same retention time as the ergosterol standard, and there were no interfering peaks (data not shown). Most other UVabsorbing components did not bind to the column. Spiking the sample with ergosterol standard did not give rise to any extra peaks. The fast atom bombardment mass spectra of extracted and authentic ergosterol revealed similar molecular masses and fragmentation patterns (data not shown). Sterols extracted from insect cuticle and elastin by the method used with mycelium were subjected to HPLC, but no peaks with retention times similar to ergosterol or ergocalciferol were detected.

Mycelium from $3 \mathrm{~d}$ CM cultures was transferred to $-\mathrm{C}-\mathrm{N}$ basal salts medium and incubated for $24 \mathrm{~h}$. The mycelium was then transferred to either CM (to give a level and rate of growth approximately equivalent to that on insect cuticle) or to $-\mathrm{C}-\mathrm{N}$ basal salts (control) and incubated for a further $24 \mathrm{~h}$. The dry weight and ergosterol content of the mycelium were measured at various times to determine the relationship between ergosterol and fungal biomass; the linearity of the graph demonstrated that the relationship between ergosterol content and fungal growth in $\mathrm{CM}$ remained constant at approximately $1.4 \mu \mathrm{g}$ per $\mathrm{mg}$ dry weight of mycelium, thus enabling ergosterol to be used as a valid measure of fungal biomass in cultures containing insoluble substrates. However, extended periods of nutrient starvation $(-\mathrm{C}-\mathrm{N})$ resulted in a reduction in ergosterol yield per mg dry weight; after 36 and $48 \mathrm{~h}$ starvation ergosterol yields fell to 1.2 and $0.95 \mu \mathrm{g} \mathrm{mg}^{-1}$ respectively. 
Table 3. Fungal biomass and PR1 production by $M$. anisopliae

\begin{tabular}{|c|c|c|c|c|}
\hline \multirow{2}{*}{$\begin{array}{l}\text { Culture } \\
\text { conditions* }\end{array}$} & \multicolumn{2}{|c|}{ Fungal growth $\nmid$} & \multicolumn{2}{|c|}{ PR1 production } \\
\hline & $\begin{array}{c}\text { Ergosterol } \\
(\mu \mathrm{g})\end{array}$ & $\begin{array}{c}\text { Dry } \\
\text { wt } \\
(\mathrm{mg})\end{array}$ & $\begin{array}{l}\text { Enzyme } \\
\text { activity } \ddagger\end{array}$ & $\begin{array}{l}\text { Activity } \\
\text { (mg } \\
\text { dry wt })^{-1}\end{array}$ \\
\hline CM $3 \mathrm{~d}$ & 361 & 260 & 0 & 0 \\
\hline$-\mathrm{C}-\mathrm{N} 0 \mathrm{~h}$ & 435 & 310 & $136 \cdot 3$ & $0 \cdot 44$ \\
\hline$-\mathrm{C}-\mathrm{N}+12 \mathrm{~h}$ & 396 & 330 & $201 \cdot 4$ & $0 \cdot 61$ \\
\hline$-C-N+24 h$ & 285 & 300 & $286 \cdot 4$ & $0 \cdot 95$ \\
\hline Cuticle $+12 \mathrm{~h}$ & 600 & 429 & $2090 \cdot 6$ & $4 \cdot 87$ \\
\hline Cuticle $+24 \mathrm{~h}$ & 975 & 696 & $3245 \cdot 2$ & $4 \cdot 66$ \\
\hline Elastin $+12 \mathrm{~h}$ & 540 & 386 & 384 & 0.99 \\
\hline Elastin $+24 h$ & 855 & 611 & $307 \cdot 9$ & $0 \cdot 5$ \\
\hline
\end{tabular}

* Mycelia were grown in CM for $3 \mathrm{~d}$, starved of $\mathrm{C}$ and $\mathrm{N}$ for $24 \mathrm{~h}$ in basal salts (shown here as $-\mathrm{C}-\mathrm{N} 0 \mathrm{~h}$ ) before addition of cuticle or elastin or continued starvation.

tDry weights for cultures containing cuticle or elastin were estimated from ergosterol content.

$\ddagger$ Enzyme activities are expressed as nmol nitroanilide released $\mathrm{ml}^{-1} \mathrm{~min}^{-1}$ from Suc-Ala-Ala-Pro-Phe-NA and represent the means of three replicates.

\section{Evaluation of insect cuticle as an inducer of PR1 production}

Cultures containing cuticle or elastin, or lacking $\mathrm{C}$ and $\mathrm{N}$ ( $-\mathrm{C}-\mathrm{N}$, control) were prepared as previously described. Elastin was chosen for comparison because, like locust cuticle, it is an insoluble protein substrate with a high proportion of alanine residues (Hojrup et al., 1986). Ergosterol was extracted and PR1 activity measured 12 and $24 \mathrm{~h}$ after addition of either cuticle or elastin. The extracted ergosterol was quantified as described above and an estimate of fungal biomass was made (Table 3). Growth in control flasks was measured conventionally by dry weight determination, as extended periods of starvation result in reduced ergosterol yields (see above).

After $12 \mathrm{~h}$ growth on cuticle, PR 1 activity was 10.4 times higher than in controls and 5.4 times higher than in cultures containing elastin. This corresponded with a 1.3and $1 \cdot 1$-fold greater biomass in cuticle cultures compared to control and elastin cultures respectively. After $24 \mathrm{~h}$ on cuticle, PR1 activity was 11.3 and 10.5 times higher than controls and elastin cultures respectively, with biomass being 1.38- and 1.07-fold greater. The high level of PR1 activity on cuticle compared with the other treatments occurred without a substantial increase in mycelial dry weight, showing that elevated PR1 levels do not result from increased fungal biomass. Analysis of enzyme activity per mg dry weight shows that protease production in cuticle cultures increased approximately eightand fivefold after 12 and $24 \mathrm{~h}$ growth compared with controls, and five- and ninefold compared with elastingrown cultures. Partial mycelial autolysis and subsequent release of intracellular enzymes may have caused the slight increase in PR1 activity seen in control $(-\mathrm{C}-\mathrm{N})$ flasks because a slight fall in mycelial dry weight was observed; thus comparisons of PR1 activity per $\mathrm{mg}$ dry weight are probably more valid after $12 \mathrm{~h}$ than $24 \mathrm{~h}$ growth.

\section{DISCUSSION}

A number of authors have suggested that protease regulation in fungi can be controlled by both induction and derepression mechanisms (reviewed by Cohen, 1980). There have been many reports of protease production being effected in fungi by exogenous protein under conditions of nutrient deprivation. Neurospora crassa produces both neutral and acid proteases if starved of either carbon, nitrogen or sulphur when grown on a protein substrate (Drucker, 1975; Cohen et al., 1975). Similar results have been described for several Candida species (Crandall \& Edwards, 1987; Banerjee et al., 1991). Proteases of certain other fungi, e.g. Mucor miebei (Lasure, 1980), and the trypsin-like protease, PR2, from $M$. anisopliae (Paterson et al., 1993) are induced nonspecifically by any protein if the fungus is starved of nitrogen, but not if starved of carbon or sulphur in the presence of nitrogen. Maximal levels of PR1 are produced only when the fungus is grown on insect cuticle as sole source of carbon and nitrogen. No PR1 was produced in media lacking carbon or sulphur and PR1 was only produced in media deficient in nitrogen if insect cuticle was included in the growth medium, in which case PR1 levels were $30 \%$ of maximal levels (achieved on $-\mathrm{C}-\mathrm{N}+$ cuticle). In all media the soluble protein BSA completely repressed PR1 production.

The exceptionally high levels of PR1 found only in cuticle-containing cultures suggest that PR1 is specifically induced by insect cuticle. An alternative explanation is that the rise in PR1 activity was due to an increase in fungal biomass. Difficulty in separating mycelium from solid substrates precluded the measurement of dry weight and therefore necessitated an alternative indicator of mycelial biomass. For this, the ergosterol content of the mycelium was determined and it was found to remain constant at $1.4 \mu \mathrm{g} \mathrm{mg}^{-1}$ dry weight during growth in CM. This compares favourably with other reported yields from fungi grown in similar conditions, for example certain Aspergillus species (Seitz et al., 1979; Shapiro \& Gealt, 1982). However, extended periods of starvation for carbon and nitrogen resulted in lower yields, which in common with similar reductions seen in ascomycete salt marsh fungi (Newell et al., 1987) could have been a result of partial mycelial autolysis.

The approximately ninefold increase in PR1 activity per mg dry weight in cuticle-containing cultures compared to controls cannot be explained by derepression alone and it is concluded that PR1 is specifically induced by some component(s), presumably proteinaceous, of insect cuticle. To the authors' knowledge, this is the first demonstration of the specific induction of a microbial protease. The significance of PR1 induction in pathogenesis is unclear. However, the specificity involved 
presumably reflects adaptation by $M$. anisopliae to insect parasitism.

\section{REFERENCES}

Andersen, S. O. (1980). Cuticular sclerotization. In Cuticle Techniques in Arthropods, pp. 185-217. Edited by T. A. Miller. New York: Springer.

Banerjee, A., Ganesan, K. \& Datta, A. (1991). Induction of secretory acid proteinase in Candida albicans. J Gen Microbiol 137, 2455-2461.

Charnley, A. K. (1984). Physiological aspects of destructive pathogenesis in insects by fungi: a speculative review. In Invertebrate Microbial Interactions (British Mycological Society Symposium 6), pp. 229-270. Edited by J. M. Anderson, A. D. M. Rayner \& D. W. H. Walton. London: Cambridge University Press.

Charnley, A. K. \& St Leger, R. J. (1991). The role of cuticledegrading enzymes in fungal pathogenesis in insects. In The Fungal Spore in Disease Initiation in Plants and Animals, pp. 267-287. Edited by G. T. Cole \& H. C. Hoch. New York \& London: Plenum Press.

Cohen, B. L. (1980). Transport and utilisation of proteins by fungi. In Microorganisms and Nitrogen Sources, pp. 412-430. Edited by J. W. Payne. San Francisco \& London: John Wiley.

Cohen, B. L. (1981). Regulation of protease production in Aspergillus. Trans Br Mycol Soc 76, 447-450.

Cohen, B. L., Morris, J. E. \& Drucker, H. (1975). Regulation of two extacellular proteases of Neurospora crassa by carbon-, nitrogen- and sulphur-metabolite repression. Arch Biochem Biophys 169, 324-330.

Cooper, R. M. \& Wood, R. K. S. (1975). Regulation of synthesis of cell wall-degrading enzymes by Verticillium albo-atrum and Fusarium oxysporum f. sp. lycopersici. Physiol Plant Pathol 5, 135-156.

Crandall, M. \& Edwards, J. E. (1987). Segregation of proteinasenegative mutants from heterozygous Candida albicans. $J$ Gen Microbiol 133, 2817-2824.

Drucker, H. (1975). Regulation of exocellular proteases in Neurospora crassa: metabolic requirements of the process. J Bacteriol $\mathbf{1 2 2}$, $1178-1125$.

Hojrup, P., Andersen, S. A. \& Roepstrorff, P. (1986). Primary structure of a structural protein from the cuticle of the migratory locust, Locusta migratoria. Biochem J 236, 713-720.

Lasure, L. L. (1980). Regulation of extracellular acid protease in Mucor miebei. Mycologia 72, 483-492.

Matcham, S. E., Jordan, B. R. \& Wood, D. A. (1984). Methods for assessment of fungal growth on solid substrates. In Microbiological
Methods for Environmental Biotechnology (Society for Applied Bacteriology Technical Series 19), pp. 5-18. Edited by J. M. Grainger \& J. M. Lynch. London \& New York: Academic Press.

Newell, S. Y., Miller, J. D. \& Fallon, R. D. (1987). Ergosterol content of salt-marsh fungi: effect of growth conditions and mycelial age. Mycologia 79, 688-695.

Paterson, I. C., Charnley, A. K., Cooper, R. M. \& Clarkson, J. M. (1993). Regulation of production of a trypsin-like protease by the insect pathogenic fungus Metarbizium anisopliae. FEMS Microbiol Lett 109, 323-328.

Seitz, L. M., Sauer, D. B., Burroughs, R., Mohr, H. E. \& Hubbard, J. D. (1979). Ergosterol as a measure of fungal growth. Phytopathology 69, 1202-1203.

Sessoms, D. B. \& Lilly, W. W. (1986). Derepressible proteolytic activity in homokaryotic hyphae of Scbizophyllum commune. Exp Mycol 10, 294-300.

Shapiro, B. E. \& Gealt, M. E. (1982). Ergosterol and lanosterol from Aspergillus nidulans. J Gen Microbiol 128, 1053-1056.

St Leger, R. J., Charnley, A. K. \& Cooper, R. M. (1987a). Characterisation of cuticle degrading proteases produced by the entomopathogen Metarbizium anisopliae. Arch Biochem Biophys 253, 221-232.

St Leger, R. J., Cooper, R. M. \& Charnley, A. K. (1987b). Distribution of chymoelastases and trypsin-like enzymes in five species of entomopathogenic deuteromycetes. Arch Biochem Biophys 258, 123-131.

St Leger, R. J., Cooper, R. M. \& Charnley, A. K. (1987c). Production of cuticle degrading enzymes by the entomopathogen Metarbizium anisopliae during infection of cuticles from Calliphora vomitoria and Manduca sexta. J Gen Microbiol 133, 1371-1382.

St Leger, R. J., Durrands, P. K., Charnley, A. K. \& Cooper, R. M. (1988a). Role of extracellular chymoelastase in the virulence of Metarhizium anisopliae for Manduca sexta. I Invertebr Pathol 52, 285-293.

St Leger, R. J., Durrands, P. K., Cooper, R. M. \& Charnley, A. K. (1988b). Regulation of production of proteolytic enzymes by the entomopathogenic fungus Metarbizium anisopliae. Arch Microbiol 150, 413-416.

St Leger, R. J., Staples, R. C. \& Roberts, D. W. (1991). Changes in translatable mRNA species associated with nutrient deprivation and protease synthesis in Metarbizium anisopliae. J Gen Microbiol 137, 807-815.

Tuksida, K. (1980). Analyis of vitamin $\mathrm{D}_{2}$ isomers. Methods Enzymol 67, 326-335.

Received 4 May 1993; revised 2 August 1993; accepted 5 August 1993 